\title{
The Development of Advance Organizer Based Distance Learning in Chemistry Bonding Material
}

\author{
Niken Widyastuti ${ }^{1 *}$, Riswandi ${ }^{2}$, Helmy Fitriawan ${ }^{3}$ \\ ${ }^{I}$ SMK SMTI Bandar Lampung, Bandar Lampung, Indonesia \\ 2,3 University of Lampung, Bandar Lampung, Indonesia
}

\section{A R T I C L E I N F O}

\section{Article history:}

Received April 07, 2021

Revised April 08, 2021

Accepted May 03, 2021

Available online May 25, 2021

\section{Kata Kunci:}

Advance Organizer, Ikatan

Kimia

Keywords:

Online Learning, Advance

Organizer, Chemical Bonding
Pembelajaran Daring,

\begin{abstract}
A B S T R A K
Penyebaran virus Covid-19 mengharuskan pemerintah mengambil kebijakan menyelenggarakan pendidikan secara online. Pembelajaran materi ikatan kimia diupayakan dikembangkan sesuai dengan kebutuhan siswa dan tujuan pembelajaran yang tercermin dalam kurikulum. Penelitian ini bertujuan untuk mengembangkan pembelajaran daring berbasis advance organizer pada materi ikatan kimia dan mengukur keefektifan pembelajaran daring tersebut. Penelitian ini menggunakan model pengembangan Dick and Carey. Subjek ujicoba pada penelitian ini adalah siswa kelas X kompetensi analisis pengujian laboratorium tahun pelajaran 2020/2021 yang berjumlah 39 siswa. Instrumen yang digunakan meliputi penilaian angket, observasi, wawancara, lembar validasi dan tes pengetahuan kognitif siswa. Data yang diperoleh dianalisis menggunakan statistic deskriptif kuantitatif dan data efektifitas pembelajaran menggunakan skor n-gain. Hasil penelitian ini didapatkan produk pembelajaran daring dengan skor validasi rata-rata sebesar 3,51 dari skala 4,00 dan nilai gain siswa sebelum dan sesudah menggunakan pembelajaran daring berbasis advance organizer adalah 0,52. Simpulan penelitian ini adalah produk pembelajaran daring berbasis advance
\end{abstract} organizer pada materi ikatan kimia sangat layak digunakan dan efektif. Temuan ini akan menjadi masukan bagi upaya pengembangan materi ikatan kimia dan penelitian pengembangan pembelajaran kimia pada saat pandemi.

\section{A B S T R A C T}

The spread of the Covid-19 virus requires the government to take a policy of organizing education online. Learning chemical bonding material is strived to be developed according to students' needs and learning objectives reflected in the curriculum. This study aims to develop advance organizer-based distance learning on chemical bonding material and measure the effectiveness of this product. This study uses the Dick and Carey development model approach. The test subjects in this study were 39 students in class X students of laboratory testing analysis competency for the 2020/2021 academic year. The instruments used included assessment questionnaires, observations, interviews, validation sheets, and students' cognitive knowledge tests. The data obtained were analyzed using quantitative descriptive statistics and data on the effectiveness of learning using an $n$-gain score. This study obtained online learning products with an average validation score of 3.51 on a scale of 4.00 , and the student gain value before and after using advance organizer-based online learning was 0.52 . This research concludes that advanced organizer-based online learning products on chemical bonding material are very feasible and practical. These findings will be an input for developing chemical bonding materials and research the development of chemistry learning during a pandemic.

This is an open access article under the CC BY-SA license.

Copyright (c) 2021 by Author. Published by Universitas Pendidikan Ganesha.

\section{INTRODUCTION}

The continuous change of the teaching framework at all school education levels has empowered the consolidation of learning and other educational environments due to the emergence of the Covid-19 pandemic (Alavudeen et al., 2021; Valverde et al., 2020). Various approaches have been carried out throughout the world where countries are affected by this disruption. Likewise, in Indonesia, the government takes an approach to change the learning system to learning at home via online or distance by looking for ways to provide learning experiences (Priantini, 2020; Wahyono, Husamah, \& Budi, 2020; Yulia, 2020). Distance learning will allow the achievement of easy and expansive teaching goals and objectives (Alavudeen et al., 2021; Prayito, 2011; Shetu et al., 2021). In other words, distance learning utilizes networks with the availability of internet networks, technological adaptability, and skills to produce different and unique learning interactions (Solehana, Asrori, \& Usman, 2019). Distance learning associates students with learning assets (information base, specialist/educator, library) that are isolated or even far apart but can talk to each other, connect or cooperate virtually. When the 
distance learning policy is the reason for anticipating a pandemic, the critical points of science must be a significant concern because this has implications for learning outcomes, and this is also identified with the quality of science itself because science is an integral part of knowledge that examines the magic and characteristics of knowledge (Kurtz, Tsimerman, \& Steiner, 2014; Sari et al., 2020). Science must also show a subject that the subject of the educated child cannot predict, and science is also studied at the secondary and tertiary levels because it combines many ideas and conceptual (Fuadi, Robbia, Jamaluddin, \& Jufri, 2020; Osman \& Sukor, 2013).

Teaching chemical resistance as part of science requires strong and big ideas as an essential subject. Such learning chemical bonding as a part of chemistry must hold a plurality which includes three prominent, macroscopic, microscopic, and symbolic depictions. The relationship and qualifications between them are essential attributes of science learning, vital for understanding synthetic ideas (Herawati \& Muhtadi, 2018; Jayadiningrat \& Ati, 2018). Chemical bonding is classified into three parts: metallic, ionic, and covalent. Multiple grasping is a topic that students generally find dangerous and builds up a wide range of confusion. So encouraging science active requires information and understanding of different scientific studies and methodologies to reach its challenges (Boesdorfer, 2019). During the Covid-19 pandemic, most chemical distance learning has proven that distance learning alternatives, such as the WhatsApp application, google classroom, zoom meeting with learning media in reading courses, digital books, and student sheets. Many students have distance learning problems in science subjects, so they are inclined towards face-to-face learning (Kimianti \& Prasetyo, 2019). Thus, developing chemistry distance learning models is a fundamental part of measuring science learning because the online learning framework requires instructors to plan the best learning model that can be applied and solve existing learning problems (Mohr \& Shelton, 2017; Rosy, Ranu, Nugraha, \& Handini, 2018)

An advance organizer is a learning model applied to distance learning initiated by David Ausubel (Elfeky et al., 2020; Joyce, Weil, \& Calhoun, 2016). Ausubel emphasized that knowledge can be learned best in an expository if ideas are structured at the beginning of the lesson. So, the application of the face-to-face advanced learning model has been widely used in chemistry subjects. The advance organizer model framework has three-stage (Mohammadi, Moenikia, \& Zahed-Babelan, 2020; Teng, 2019). The first stage is the advance organizer presentation, where the idea of the material comprises explaining learning targets, introducing a development coordinator, and empowering familiarity with earlier information. The second stage is the presentation of learning assignments or learning materials in presentations, discussions, films, experiments, or reading. The third stage examines the relationship between learning materials and the idea of carrying out an active learning process, consisting of four activities: encouraging integrative reconciliation, encouraging active acceptance learning, explaining critical approaches, and clarifying ideas. The advanced organizer model has been widely applied in face-to-face chemistry learning. The advanced organizer model in face-to-face chemistry learning has been applied to atomic structure materials, molecular chemistry materials, colloid chemicals, basic chemicals, electrolyte and non-electrolyte solution materials, and buffer solution materials (Mardiah, 2016; Maryam, Ratman, \& Ningsih, 2018; Mastiah, Nurlaili, \& Muflihah, 2018; Reskiani \& Supriadi, 2020; Suharti, Naswir, \& Dewi, 2019). The findings above indicate that the advance organizer model's application can significantly differ in results and is effectively used in the face-to-face chemistry learning process.

The authors intend to combine distance learning with an advanced organizer learning model in a chemistry learning process in this development research. However, it is seldom to find the development research that combines online learning with an advanced organizer learning model in a chemistry learning process. In the others learning subject, the combination of distance learning with advanced organizer learning models can be developed into a meaningful learning experience for students. Advanced organizer is an attractive organizational tool in conventional homeroom guides, can enhance student data education in self-coordinated online classrooms (Lin \& Chen, 2016; Mortazavi, 2011). Online Advance Organizer Concept Teaching Material (ONACOM) is successful were learning with little but being able to pay attention to courses and strategies when methodically incorporated into teaching strategies (Yilmaz \& Korur, 2021). TThis research is essential to develop because distance chemistry learning is expected to provide meaningful and quality learning experiences for students even in the pandemic era.

Furthermore, the evaluation of this advance organizer-based distance learning is carried out by measuring the level of learning effectiveness. The effectiveness and productivity of learning are one of the benchmarks for the quality of education which is often measured by achieving learning objectives guided by the educational curriculum directed by the government (Lase, 2019; Za'im, 2016). Effective learning provides opportunities for students to learn independently so that personalized learning occurs so that students can carry out learning activities as widely as possible to help themselves understand and apply the required concepts by the learning (Mutakinati, Anwari, \& Yoshisuke, 2018; Suryadewi, Wiyasa, \& Sujana, 2020). Measurement of learning effectiveness and productivity is calculated based on the students' scores on the pretest and posttest using the n-gain value (Ayuni, Kusmariyatni, \& Japa, 2017; Putra \& Sujana, 2020). The adequacy of science 
adaptation needs to be estimated to determine the extent to which the achievement of the science learning cycle remotely on the holding material for compound chemistry can be applied. Thus, we can describe this research's purpose of developing an advanced organizer-based distance learning on the chemical bonding material and measuring the effectiveness of the advance organizer learning model in class laboratory testing analysis competency at SMK SMTI Bandar Lampung the 2020/2021 academic year.

\section{METHOD}

As research on the development of distance learning methods, this research method uses experiments to see the results of distance learning products and test their effectiveness. The development model used is a modification of The Dick and Carey's systems approach model to design a research and development model instruction (Dick, Carey, \& Carey, 2015). The Dick and Carey's systems approach model has ten steps that can be seen in the following Figure 1.

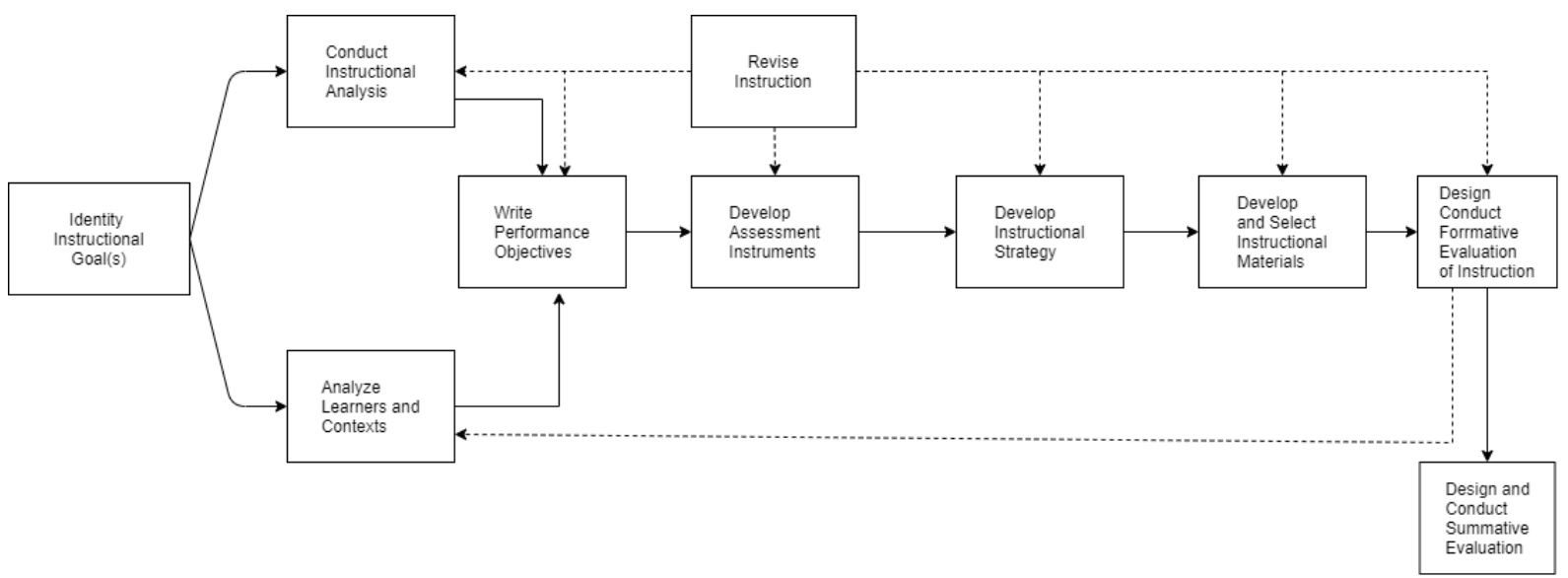

Figure 1. The Model of Dick and Carey approach (Dick et al., 2015)

The test subjects in this study were 39 students of class $\mathrm{X}$ testing analysis laboratory competencies in SMK SMTI Bandar Lampung divided where are three students for the one-to-one evaluation test, nine students for the small group evaluation process, and 27 students for analyzing learners process and field evaluation process. The data used in this study were primary. Data were obtained directly from students' opinions about needed distance learning in chemical bonding materials before doing the development research, responses about the usefulness during the research development, and the effectiveness of distance learning in chemical bonding materials after they used this product. Besides that, data was obtained from chemical content validator, learning design validator, and learning media validator responses about the quality of advanced organizer-based distance learning in chemical bonding products through a questionnaire given then analyzed and interview.

The instruments used in this research for students include questionnaires, interviews sheets, observations sheets, and knowledge evaluation sheets. The instruments used for validators include validation sheets and interview sheets used to determine the validity of advance organizer-based distance learning in chemical bonding products. After collecting the data, the data were analyzed in a combination of qualitative and quantitative ways. Likewise, the learning and questionnaire validation data were analyzed compared to the validity criteria (Lukman \& Ishartiwi, 2014). Furthermore, in the evaluation stage, we used experimental group pretest and post-test design to analyze student outcomes by involving the n-Gain formula based on the pre-test and post-test results

\section{RESULT AND DISCUSSION}

The improvement of advance organizer put together distance learning with respect to substance science material produces e-learning distributed in google classroom. The content of e-learning can be found in Table 1.

Table 1. Materials of e-learning

\begin{tabular}{llll}
\hline Part & Content & Materials & Syntax of Advance Organizer \\
\hline 1 & Introduce and Pretest & - Introducing video & - \\
& & - & Online instructional video \\
\hline
\end{tabular}




\begin{tabular}{|c|c|c|c|}
\hline Part & Content & Materials & Syntax of Advance Organizer \\
\hline 2 & Atoms & $\begin{array}{l}\text { - } \text { Sheet of knowledge assessment } \\
\text { - } \text { Atomic video } \\
\text { - } \text { Exercise of concept atom }\end{array}$ & 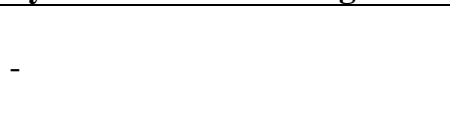 \\
\hline 3 & Organizing Learning & $\begin{array}{l}\text { Advance organizer of chemical bonding } \\
\text { video }\end{array}$ & Phase one \\
\hline 4 & Ionic bonding & $\begin{array}{l}\text { - Ionic bonding video } \\
\text { - Exercise of ionic bonding concept }\end{array}$ & Phases two and three \\
\hline 5 & Covalent bonding & $\begin{array}{l}\text { - Covalent bonding video } \\
\text { - Exercise of covalent bonding } \\
\text { concent }\end{array}$ & Phases two and three \\
\hline 6 & Metallic bonding & $\begin{array}{l}\text { - Metallic bonding video } \\
\text { - Exercise of metallic bonding concept }\end{array}$ & Phases two and three \\
\hline 7 & Posttest & Sheet of knowledge assessment & - \\
\hline
\end{tabular}

This product is validated by the chemical content validator, the learning design validator, and the learning media validator. According to the validator, the validity of this product is in the following Table 2.

Table 2. Validity Result

\begin{tabular}{ccc}
\hline Trial Subject & Validity Result & Criteria \\
\hline Chemical Content Validator & 3.50 & Great \\
Learning Design Validator & 3.36 & Great \\
Learning Media Validator & 3.67 & Great \\
One-to-one Evaluation & 3.50 & Great \\
Small Group Evaluation & 3.46 & Great \\
Field trial Evaluation & 3.42 & Great \\
\hline
\end{tabular}

This product has been tested and rated by a chemical content validator with a score of 3.50 in excellent criteria. Validators provide feedback to add content about cation and anion formation in the ionic bonding video and add exercise content in each new section of the discussion. The suggestions are then followed up and checked again by the content validator. The validity result scored of the learning design validator is 3.36 with significant criteria. The validator provides feedback to make learning objectives following the CABD (Condition Audience Behavior and Degree) formulation and develops instructional analysis and concept structures from the advanced organizer model's basic concepts. These suggestions are then followed up and checked again by the learning design validator. The validity result scored from the learning media validator is 3.67 with significant criteria. The validator provides several inputs. Include the video section's time to quickly find the part of the video they need and open a discussion forum that connects with the teacher to get closer to the teacher if there are difficulties.

The ideas are then followed up and twofold checked by the media instructional validator. After all the approval measures, this item is assessed by students in three stages. Stage one will be a coordinated assessment; in this stage, the creator works exclusively with three students who address the gathering's rangeability. In one is one-to-one evaluation, the validity score is 3.50 with significant criteria. The interviewed process gave feedback to replace the animated teacher picture with the teacher video explaining the materials and changing the white background with colorful colors. Stage two is a small group evaluation with nine learners as a participant. The scored validity of small group evaluation is 3.46 , with significant criteria. The results of the small group evaluation of all students strongly agree with advance organizer-based online learning, which is presented both in terms of ease of access, completeness of the material, explanation of material in the learning video, video duration, understanding of the language used, display of letters and supporting animation. Stage three is field trial evaluation with a twenty-seven learner who represents the rangeability in the group. Infield evaluation, the validity scored is 3.42 , with significant criteria. This means that advanced organizer-based distance learning can be used because it follows SMK SMTI Bandar Lampung students' learning preferences that can be seen in the following figure 2 . The application of the advance organizer learning model with instructional videos is designed to provide meaningful experiences for students. As shown in Table 1, in part two, the presentation of the atomic video aims to recall students' memories and strengthen the atomic concept scheme as a basic concept for the chemical bonding material. This strengthening process will facilitate the integrative reconciliation process expected by Ausubel in the advance organizer learning model. As indicated by Ausubel's hypothesis, understudies should relate compound holding materials as new information to what they know previously to adapt genuinely. The ideas of synthetic holding are based upon the basic standards of nuclear design; this 
comprehension of substance conduct at the nuclear level seems fundamental in understanding the compound holding idea.

Part three in Table 1 presented the aim of learning and an advanced organizer of chemical bonding. The advanced organizer helps students link their ideas with new concepts. In this stage, a progressive differentiation process occurs. Progressive differentiation means that the most common idea of a discipline is initially a gradual increase in detail (Mohammadi et al., 2020; Suharti et al., 2019; Trisnadewi, Putra, \& Ardana, 2020). Presented advance organizer as a hierarchy of chemical bonds at the beginning of the lesson makes it easier for students to find out the main ideas in this material where cause and effect relationships can be easily observed. Part four until six in Table 1 presented ionic bonding, covalent bonding, and metal bonding materials learning. Each meeting begins with presenting learning videos and examining the relationship between learning materials and ideas. Learning videos help students understand the material quickly (Andriyani \& Suniasih, 2021; Priantini, 2020; Wisada, Sudarma, \& Yuda S, 2019). At this stage, an integrative reconciliation process can occur. The integrative reconciliation process conveys the details of new ideas by linking them with the previous material. This process is necessary to obtain a complete abstract picture of chemical bonds. To support the relationship between theory and fact, students can perform simple experiments dissolving some of the chemicals around them, showing differences in solubility between compounds with different bond types. This method can connect all the concepts of chemical bonding taught by students by providing deep experience and meaningful learning. The effectiveness of advance organizer-based distance learning measured by n-gain scored. Based on the results, it was obtained an average n-gain value of 0.52 with medium effectiveness criteria. The circulation of information data on the effectiveness test can be found in Figure 3.

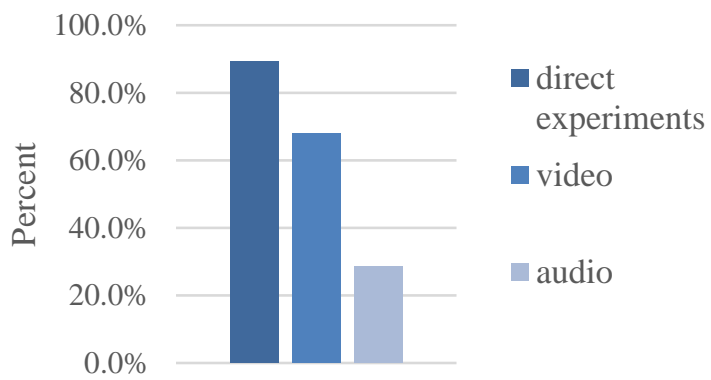

Figure 2. Students' learning preferences.

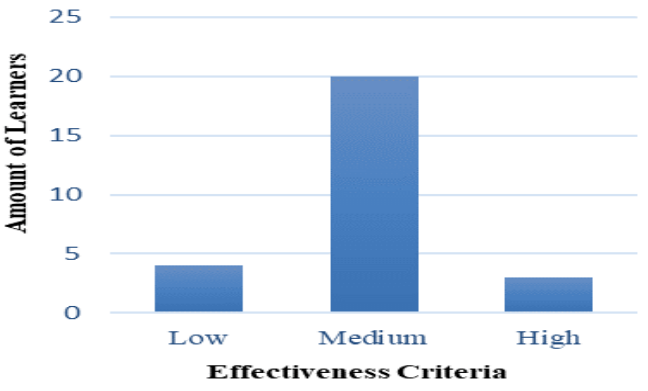

Figure 3. The circulation of information data on the effectiveness test

Given Figure 3, there are four students with low effectiveness criteria, twenty students on medium effectiveness criteria, and three high effectiveness criteria. From these outcomes, it tends to be seen that advance organizer-based distance learning contrastingly affects understudies. This difference in results can occur due to several things - first, independence in the distance learning process. As known, distance learning requires high independence and requires good intrinsic motivation from students. The students' independent character in the learning process can be shown based on their motivation to choose SMK SMTI Bandar Lampung as their school, as shown in Figure 4.

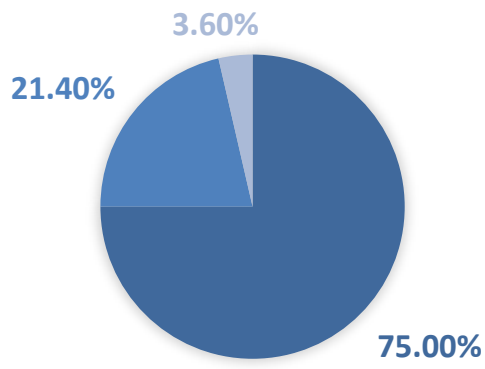

\author{
own motivation \\ - forced by their parents \\ the others thing
}

Figure 4. The students' characteristic.

Based on the results of the students' characteristics in Figure 4, it is known that $75.0 \%$ of students choose schools at SMK SMTI Bandar Lampung because of their motivation to work immediately. This data describes that $75.0 \%$ of students have intrinsic motivation to be independently involved in the learning process and achieve success to work immediately after graduating from school. On the other side, $21.4 \%$ of students choose SMK SMTI Bandar Lampung because of their parents, and 3.6\% force them because of other things. 
Selection of schools that are not by student interests can affect student activity in the learning process and student learning outcomes. Second, misconceptions in understanding chemical bonding materials. Misconceptions can occur when students have such strong misinterpretations that even after learning the right ideas in the classroom, they are resistant to adjusting their previous thinking (Lukitasari et al., 2019; McNamara et al., Greene, 2020). In implementing distance learning, the discussion process did not run optimally for all students. Not all students are interested and involved in the direct discussion in groups or individually. Even though e-learning has provided the facility with questions directly to the teacher, only a few students take advantage of this facility. Students involved in the discussion only focus on a few students; when the teacher tries to pay attention to students who are not active, not all students respond actively. If this process is not optimal, it can cause misconceptions because there is no clarification of the material being studied.

Third, distance learning has shortcomings. There are expected understudies to have self-control, sensations of separation, and cutoff points peer learning (Kalantarrashidi, Mohammadpour, \& Sahraei, 2015; Vernadakis et al., 2012). Web-based learning detriments are high odds of interruption, muddled technology, no friendly communication, and trouble remaining in contact with educators (Lasminiasih, 2016; Sadegi, 2019). These components can influence the adequacy of online learning by understudies. Given the shortcomings, it is fundamental to shaping cooperation exercises and framing a climate in an online learning framework (Kaplan, 2018). The degree to which understudies are associated with online learning programs and talk about the ideas they comprehend will decide the degree of their involvement with getting sorted out and mirroring their insight regarding compound bonds. This research implies that the development of advance organizer-based distance learning on chemical bonding material can improve the understanding of chemical bonding and provide meaningful learning according to students' learning choices. In the future, this product can be used by students in grades X, XI, and XII in the school's Learning Management System (LMS). Students who do not understand or forget about the concept of chemical bonds can be directed by the teacher to study this product independently and other class materials that require a connection with the concept of chemical bonds.

\section{CONCLUSION}

Based on the research results, the conclusions were obtained by the advanced organizer-based online learning model on chemical bonding material. This learning model is feasible to use based on content experts, media experts, and learning design experts, with an average score of 3.51 with significant criteria. The effectiveness value of using $\mathrm{n}$-gain shows a result of 0.52 with medium effectiveness criteria.

\section{REFERENCES}

Alavudeen, S. S., Easwaran, V., Mir, J. I., Shahrani, S. M., Aseeri, A. A., Khan, N. A., \& Asiri, A. A. (2021). The influence of COVID-19 related psychological and demographic variables on the effectiveness of elearning among health care students in the southern region of Saudi Arabia. Saudi Pharmaceutical Journal, 9. https://doi.org/https://doi.org/10.1016/j.jsps.2021.05.009.

Andriyani, N. L., \& Suniasih, N. W. (2021). Development Of Learning Videos Based On Problem-Solving Characteristics Of Animals And Their Habitats Contain in Science Subjects On 6th-Grade. Journal of Education, 5(1), 37-47. https://doi.org/http://dx.doi.org/10.23887/jet.v5i1.32314.

Ayuni, I. A. S., Kusmariyatni, N., \& Japa, I. G. N. (2017). Pengaruh Model Pembelajaran Talking Stick Berbantuan Media Question Box Terhadap Hasil Belajar IPA Kelas V. Journal of Education Technology, 3(1). https://doi.org/http://dx.doi.org/10.23887/jet.v1i3.12503.

Boesdorfer, S. B. (2019). Growing Teachers and Improving Chemistry Learning: How Best Practices in Chemistry Teacher Education Can Enhance Chemistry Education. ACS Symposium Series, 1(1). https://doi.org/https://doi.org/10.1021/bk-2019-1335.ch001.

Dick, W., Carey, L., \& Carey, J. O. (2015). The Systematic Design Of Instruction (8 ed.). America: The United States of America.

Elfeky, A. I. M., Masadeh, T. S. Y., Articles, R., Model, R. Q. in E. E. through the F. C., Procedia Computer Science, Volume 172, 2020, pp. 906-914, Details, D. Pdfv., ... Elbyaly, M. Y. H. (2020). Advance organizers in flipped classroom via e-learning management system and the promotion of integrated science process skills. Thinking Skills and Creativity, 35. https://doi.org/https://doi.org/10.1016/j.tsc.2019.100622.

Fuadi, H., Robbia, A. Z., Jamaluddin, J., \& Jufri, A. W. (2020). Analisis Faktor Penyebab Rendahnya Kemampuan Literasi Sains Peserta Didik. Jurnal Ilmiah Profesi Pendidikan, 5(2). https://doi.org/https://doi.org/10.29303/jipp.v5i2.122.

Herawati, N. S., \& Muhtadi, A. (2018). Pengembangan Modul Elektronik (E-Modul) Interaktif Pada Mata Pelajaran Kimia kelas XI SMA. Jurnal Inovasi Teknologi Pendidikan, 5(2), 180-191. 
https://doi.org/https://doi.org/10.21831/jitp.v5i2.15424.

Jayadiningrat, M. G., \& Ati, E. K. (2018). Peningkatan Keterampilan Memecahkan Masalah Melalui Model Pembelajaran Problem Based Learning (Pbl) Pada Mata Pelajaran Kimia. Jurnal Pendidikan Kimia Indonesia, 2(1), 1. https://doi.org/10.23887/jpk.v2i1.14133.

Joyce, B., Weil, M., \& Calhoun, E. (2016). Models of Teaching (9 ed.). Yogyakarta: Pustaka Pelajar.

Kalantarrashidi, S. A., Mohammadpour, E., \& Sahraei, F. (2015). Effect of Blended Learning Classroon Environment on Student's Satisfaction. Journal of Educaion and Training Studies, 3(5), 225-230. https://doi.org/https://doi.org/10.11114/jets.v3i5.1013.

Kaplan, D. E. (2018). Piagetian Theory in Online Teacher Education. Scientific Research Publishing, 9(6). https://doi.org/https://doi.org/10.4236/ce.2018.96061.

Kimianti, \& Prasetyo. (2019). Pengembangan E-Modul IPA Berbasis Problem Based Learning Untuk Meningkatkan Literasi Sains Siswa. Kwangsan Jurnal Teknologi Pendidikan, 7(2). https://doi.org/https://doi.org/10.31800/jtp.kw.v7n2.p91--103.

Kurtz, G., Tsimerman, A., \& Steiner, O. (2014). The Flipped Classroom Answer to Future Learning? European Journal of Open, Distance and E-Learning, 17(2). https://doi.org/https://doi.org/10.2478/eurodl-20140027.

Lase, D. (2019). Pendidikan di Era Revolusi Industri 4.0. Jurnal Sundermaan, 1(1). https://doi.org/https://doi.org/10.36588/sundermann.v1i1.18.

Lasminiasih, D. (2016). Perancangan Sistem Informasi Kredit Mikro Mahasiswa Berbasis Web. Jurnal Sistem Informasi (Journal of Information System), 8(1), 883-893. https://doi.org/https://doi.org/10.36706/jsi.v8i1.2957.

Lin, H., \& Chen, T. (2016). Decreasing cognitive load for novice EFL learners: Effects of question and descriptive advance organizers in facilitating EFL learners' comprehension of an animation-based content lesson. System, 34(3). https://doi.org/https://doi.org/10.1016/j.system.2006.04.008.

Lukitasari, Purnamasari, Utami, \& Sukri. (2019). Blended-Problem-Based Learning: How its impact on students' critical thingking skills? Jurnal Pendidikan Biologi Indonesia, 5(3), 425-434. https://doi.org/https://doi.org/10.22219/jpbi.v5i3.10048.

Lukman, \& Ishartiwi. (2014). Pengembangan Bahan Ajar Dengan Model Mind Map Untuk Pembelajaran Ilmu Pengetahuan Sosial SMP. Jurnal Inovasi Teknologi Pendidikan, I(2). https://doi.org/https://doi.org/10.21831/tp.v1i2.2523.

Mardiah, A. (2016). Penggunaan Model Pembelajaran Advance Organizer Dalam Meningkatkan Hasil Belajar Siswa Pada materi Struktur Atom. Lantanida Journal, 4(2). https://doi.org/https://doi.org/10.22373/lj.v4i2.1886.

Maryam, Ratman, \& Ningsih, P. (2018). Pengaruh Model Pembelajaran Advance Organizer Terhadap Hasil Belajar Siswa SMA Negeri 3 Sigi Pada Materi Larutan Elektrolit Dan Non Elektrolit. Jurnal Akademika Kimia, 7(2). https://doi.org/https://doi.org/10.22487/j24775185.2018.v7.i2.10392.

Mastiah, S., Nurlaili, \& Muflihah. (2018). Analisis Kemampuan Berpikir Kritis Siswa Melalui Model Pembelajaran Advance Organizer Pada Materi Larutan Elektrolit Dan Nonelektrolit. Bivalen: Chemical Studies Journal, 1(2). https://doi.org/http://jurnal.fkip.unmul.ac.id/index.php/bivalen.

McNamara, J., Sweetman, S., Connors, P., Lofgren, I., \& Greene, G. (2020). Using Interactive Nutrition Modules to Increase Critical Thinking Skills in College Courses. Journal of Nutrition Education and Behavior, 5(4). https://doi.org/https://doi.org/10.1016/j.jneb.2019.06.007.

Mohammadi, M., Moenikia, M., \& Zahed-Babelan, A. (2020). The role of advance organizer on English language learning as a second language. Procedia - Social and Behavioral Sciences, 2(2). https://doi.org/https://doi.org/10.1016/j.sbspro.2010.03.747.

Mohr, S. C., \& Shelton, K. (2017). Best Practices Framework for Online Faculty Professional Development: A Delphi Study. Online Learning Journal, 21(4). https://doi.org/https://doi.org/10.24059/olj.v21i4.1273.

Mortazavi, S.-M. (2011). The relationship between time lapse between introducing lexical advance organizers and video viewing, and comprehension in a foreign language classroom. Procedia - Social and Behavioral Sciences, 15. https://doi.org/https://doi.org/10.1016/j.sbspro.2011.04.047.

Mutakinati, L., Anwari, I., \& Yoshisuke, K. (2018). Analysis of students' critical thinking skill of middle school through stem education project-based learning. Jurnal Pendidikan IPA Indonesia, 7(1), 54-65. https://doi.org/10.15294/jpii.v7i1.10495.

Osman, K., \& Sukor, N. S. (2013). Conceptual Understanding in Secondary School Chemistry: A Discussion of the Difficulties Experienced by Students. American Journal of Applied Sciences, 10(3). https://doi.org/https://doi.org/:10.3844/ajassp.2013.433.441.

Prayito. (2011). Pengembangan Perangkat Pembelajaran Matematika Humanistik Berbasis Konstruktivisme Berbantuan E-Learning Materi Segitiga Kelas VII. AKSIOMA Journal of Mathematics Education, 2(2). https://doi.org/https://doi.org/10.26877/aks.v2i2/Septembe.37. 
Priantini, D. A. (2020). The Development Of Teaching Video Media Based On Tri Kaya Parisudha In Educational Psychology Courses. Journal of Education Technology, 4(4). https://doi.org/http://dx.doi.org/10.23887/jet.v4i4.29608.

Putra, I. G. D., \& Sujana. (2020). Hasil belajar IPS menggunakan Kolaborasi Model Discovery Learning Berbasis Media Animasi. Journal of Educational Technology, 4(1), 103-109. https://doi.org/http://dx.doi.org/10.23887/jet.v4i2.25099.

Reskiani, \& Supriadi. (2020). Implementation of Advance Organizer learning Model Based on Numbered Heads Together (NHT) to Improve Learning Outcomes of Studeny in 11th Grade Science on Buffer at SMAN 2 Balaesang. Jurnal Akademika Kimia, 9(2). https://doi.org/:10.22487/j24775185.2020.v9.i3.pp1

Rosy, B., Ranu, M. E., Nugraha, J., \& Handini, H. T. (2018). Pelatihan Media Pembelajaran Berbasis ELearning, Schoology Bagi Guru SMK Program Keahlian Administrasi Perkantoran Di Kabupaten Jombang Jawa Timur. Jurnal Pemberdayaan Masyarakat Madani, 2(2). https://doi.org/https://doi.org/10.21009/JPMM.002.2.02.

Sadegi, M. (2019). A Shift Ftom Classroom to Distance Learning: Advantages and Limitation. International Journal of Research in English Education ( IJREE), 4(1). https://doi.org/https://doi.org/10.29252/ijree.4.1.80.

Sari, Sinaga, Hernani, \& Solfarina. (2020). Chemistry Learning via Distance Learning during the Covid-19 Pandemic. TADRIS (Journal of Education and Teacher Training), 5(1). https://doi.org/https://doi.org/10.24042/tadris.v5i1.6346.

Shetu, S. F., Rahman, M. M., Ahmed, A., Mahin, M. F., Akib, M. A. U., \& Saifuzzaman, M. (2021). Impactful e-learning framework: A new hybrid form of education. Current Research in Behavioral Sciences, 2. https://doi.org/https://doi.org/10.1016/j.crbeha.2021.100038.

Solehana, L., Asrori, A., \& Usman, A. (2019). The Development of E-Learning Teaching Material Based on Edmodo on Basic Competencies of National Integration at Class X of Senior High School. Journal Of Education, Teaching And Learning, 4(2). https://doi.org/https://doi.org/10.26737/jetl.v4i2.1914.

Suharti, K., Naswir, M., \& Dewi, F. (2019). Pengaruh Model Pembelajaran Advance Organizer Terhadap Kemampuan Siswa Menganalisis Materi Bentuk Molekul Kelas X IPA SMA Negeri 10 Kota Jambi. Journal of The Indonesian Society of Integrated Chemistry, 11(1). https://doi.org/https://doi.org/10.22437/jisic.v11i1.6660.

Suryadewi, N. K. A., Wiyasa, I. K. N., \& Sujana, I. W. (2020). Kontribusi Sikap Mandiri dan Hubungan Sosial Terhadap Kompetensi Pengetahuan IPS. MIMBAR PGSD Undiksha, 8(1), $29-39$. https://doi.org/http://dx.doi.org/10.23887/jjpgsd.v8i1.24576.

Teng, M. F. (2019). The effects of video caption types and advance organizers on incidental L2 collocation learning. Computers \& Education, 142. https://doi.org/https://doi.org/10.1016/j.compedu.2019.103655

Trisnadewi, N. K., Putra, M., \& Ardana, I. K. (2020). Model Advance Organizer Berbantuan Media Grafis Berpengaruh Terhadap Kompetensi Pengetahuan IPS. Mimbar Ilmu Undiksha, 25(2), 1-12. https://doi.org/http://dx.doi.org/10.23887/mi.v25i2.25152.

Valverde-Berrocoso, Garrido-Arroyo, Burgos-Videla, \& Morales-Cevallos. (2020). Trends in Educational Research about e-Learning: A Systematic Literature Review (2009-2018). Sustainability, 12(12). https://doi.org/doi:https://doi.org/10.3390/su12125153.

Vernadakis, Giannous, Derri, Michalopoulos, \& Kioumourtzoglou. (2012). The impact of blended and traditional instruction in students performance. In Procedia Technology, 1(1), 439-443. https://doi.org/https://doi.org/10.1016/j.protcy.2012.02.098.

Wahyono, P., Husamah, H., \& Budi, A. S. (2020). Guru profesional di masa pandemi COVID-19: Review implementasi, tantangan, dan solusi pembelajaran daring. Jurnal Pendidikan Profesi Guru, 1(1), 51-65. https://doi.org/https://doi.org/10.22219/jppg.v1i1.12462.

Wisada, P. D., Sudarma, I. K., \& Yuda S, A. I. W. I. (2019). Pengembangan Media Video Pembelajaran Berorientasi Pendidikan Karakter. Journal of Education Technology, 3(3), 140. https://doi.org/10.23887/jet.v3i3.21735

Yilmaz, E., \& Korur, F. (2021). The Effects of an Online Teaching Material Integrated Methods on Students' Science Achievement, Attitude and Retention. International Journal of Technology in Education, 4(1). https://doi.org/https://doi.org/10.46328/ijte.79.

Yulia. (2020). Online Learning to Prevent the Spread of Pandemic Corona Virus in Indonesia. ETERNAL (English Teaching Journal), 11(1). https://doi.org/https://doi.org/10.26877/eternal.v11i1.6068.

Za'im, M. (2016). Pendidikan Anak dalam Pengembangan Kecerdasan IQ, EQ dan SQ (Studi Kitab Tuhfat Al Mawdud Bi Ahkam Al- Mawlud Karya Ibnu Al- Qayyim Al- Jauziyah). Muallimuna: Jurnal Madrasah Ibtidaiyah, 2(1). https://doi.org/https://doi.org/10.31602/muallimuna.v2i1.743. 